\title{
Reproductive Performance of Female Kacang Goats Supplemented by Mineral Under a Tethering Feeding System
}

\author{
Khalil $^{\mathrm{a}, *}$, A. Bachtiar ${ }^{\mathrm{b}}$, \& Evitayani ${ }^{\mathrm{a}}$ \\ aDepartment of Nutrition and Feed Technology, Faculty of Animal Science, Andalas University, \\ Campus II Payakumbuh, Sumatera Barat, Indonesia \\ bDepartment of Livestock Business and Social, Faculty of Animal Science, Andalas University, \\ Campus Limau Manis Padang, Sumatera Barat, Indonesia \\ *Corresponding author: khalil@ansci.unand.ac.id \\ (Received 14-05-2019; Revised 07-07-2019; Accepted 25-07-2019)
}

\begin{abstract}
Inadequate feed intake and nutrient supply are associated with the suboptimal reproductive performance of Kacang goats reared using a traditional tethering system in the Pariaman region of Indonesia. The objectives of this study were to (i) identify reproductive problems in tethered female Kacang goats, (ii) assess crude nutrient and mineral composition of feed consumed by tethered goats, and (iii) evaluate the beneficial effects of mineral supplementation on reproductive performance of tethered female Kacang goats. A field survey was carried out in Pariaman City and the Padang Pariaman Regency to collect data on reproductive performance as well as blood mineral and hematological profiles of tethered female Kacang goats. Forage and feed samples were collected and analyzed for dry matter (DM), crude protein (CP), and minerals (Ca, $\mathrm{P}, \mathrm{Mg}, \mathrm{Fe}, \mathrm{Cu}$, and $\mathrm{Zn}$ ) contents. Feed was formulated with supplemented complete minerals in either block form or mixed with feed. A total of 15 young female Kacang goats received feed without supplement $(\mathrm{P0}, \mathrm{n}=5)$, or mineral supplement with feed $(\mathbf{P 1}, \mathrm{n}=5)$, or in a manually prepared block lick $(\mathbf{P 2}, \mathbf{n}=5)$. Parameters measured included body weight, number of pregnant goats, blood mineral concentrations, hematological parameters, total protein concentrations, and progesterone concentrations. Results of the field survey showed that the age of maturity of female Kacang goats reared under a tethering system ranged between 5 and 9 months and the first kidding occurred between 12 and 23 months. The suboptimal reproductive performance of female Kacang goats raised using a tethering system was closely related to the inadequate feed intake and nutritional deficiency. Supplementation with minerals is an effective method to enhance nutritional status and health to increase pregnancy rate of tethered female Kacang goats.
\end{abstract}

Keywords: Kacang goat; local mineral; tethering; reproduction

\section{INTRODUCTION}

Kacang goat (Capra hircus) is an indigenous dwarf breed of goat that is used as a meat source and is widely reared as a side business on farms in Indonesia due to the ability of these goats to reproduce and survive with simple rearing and feeding practices. These goats are commonly raised in small flocks that are confined in a simple colony house at night and tethered to graze, typically from noon through the late afternoon. The animals are tethered around the village in house yards, crop plantations (banana, coconut), idle land, road-sides, riverbanks, or beside irrigation canals. The tethered grazing system allows wild vegetation to grow in crop plantation areas and on unused land to be used as feed sources while preventing goats from straying into crop gardens where they could consume food crops or other valuable plants.

The amount of feed and nutrient intake by tethered goats is usually below their nutritional requirements due to the limited grazing area and time. Tethered goats are allowed to graze on wild vegetation accessible at the end of the tether for around 4-5 hours per day. Daily forage intake can also fluctuate due to selective foraging behavior, irregular movement, and several uncontrolled factors, such as seasonal forage availability, rain, and competition with the other livestock species (e.g., cattle, buffalo). To compensate for feed inadequacies, some farmers give their goats concentrates made from locally available agro-industrial by-products, such as lowergrade rice bran and chopped sago stalk. Such supplementary concentrate can fulfill daily energy requirements of goats, but tethered goats often have protein and mineral deficiencies that can cause health problems and suboptimal reproductive performances. Wild vegetation and agro-industrial byproducts not only vary in dry matter (DM) and crude nutrient content, but also often have low mineral content (Khalil et al., 2015; Khalil, 2016). For female Kacang goats raised on a small farm using a tethered grazing system, reproductive per- 
formances could vary due to the inconsistent feed intake and nutrient deficiency.

Tethered goats typically require feed supplements to meet nutrient and mineral requirements needed to optimize health and reproductive potential. The farmers of Kacang goat can be challenged to obtain protein supplements due to the scarcity of protein sources and high cost. In contrast, only small amounts of mineral are needed to resolve mineral deficiencies which can also have adverse effects on both animal reproduction and health (Suttle, 2010). Moreover, mineral feed supplements can be produced using locally available ingredients. In West Sumatra, stone meal from Bukit Kamang, fresh-water mussel-shell meal, and bone-char meal are often used for mineral supplements. These local resources are particularly good sources of $\mathrm{Ca}$ and $\mathrm{P}$ (Khalil et al., 2018; Khalil et al., 2017). Bukit Kamang' stone meal is also rich in essential micronutrients, including manganese (Mn) (205 ppm), iron (Fe) (295 ppm), and selenium (Se) (388 ppm) (Khalil et al., 2012). Minerals that are important for reproductive performance and are commonly monitored in the blood serum of ruminants are $\mathrm{Ca}, \mathrm{P}$, $\mathrm{Mg}, \mathrm{Fe}, \mathrm{Mn}, \mathrm{Zn}$, and $\mathrm{Cu}$ (Mude et al., 2010; Akhtar et al. 2014; Sahoo et al., 2016; Niaz et al., 2017). Therefore, local materials used for mineral supplements can be mixed and enriched with dicalcium phosphate as well as $\mathrm{Cu}$ and $\mathrm{Zn}$ to produce a complete mineral mixture. Such mineral supplements are predicted to improve the nutritional status of goats and in turn improve the health and reproductive performance of these animals.

This study was designed to assess how reproductive problems of female Kacang goats reared under a traditional tethered system are related to feed as well as nutritional and health status. The second objective of this study was to evaluate the beneficial effects of mineral supplementation using locally available materials. The supplements were formulated based on mineral profiles of the existing feed. Body weight, hematological values, mineral, progesterone, blood protein concentration, and reproductive performance of tethered female Kacang goats given minerals supplementation either mixed in the feed or in block form were measured and compared to goats without mineral supplementation.

\section{MATERIALS AND METHODS}

\section{Survey of Reproductive Performance}

The study was initiated by conducting a field survey in April 2018 to assess the reproductive performance of 100 female Kacang goats raised using a tethered system on 33 small farms, which were distributed among seven villages (Kaluat, Kampuang Kandang, Toboh Palabah, Koto Marapak, Kajai, Pungguang Ladiang, and Santok) located in the Pariaman City and Padang Pariaman Regency, West Sumatra, Indonesia. The study sites in the Pariaman Region were located in coastal locations, between $0^{\circ} 11^{\prime}$ to $0^{\circ} 49^{\prime}$ south latitude and $98^{\circ}$ $36^{\prime}$ and $100^{\circ} 28^{\prime}$ east longitude at an altitude of 0-100 $\mathrm{m}$. The region has a tropical, humid climate, and an ambient temperature that ranges from 21 to $31^{\circ} \mathrm{C}$ with an average relative humidity of $85 \%$. The average an- nual rainfall is $368.4 \mathrm{~cm}$ with a mean 19 rainy days per month. The dominant type of crops grown in this region is coconut, banana, and paddy rice. The main livelihood of residents in this area is crop farming and fishing.

The average flock size reared by the selected farms was 7.1 goats, which included does, bucks, and kids (average 3.1, 3.0, and 2.3 heads/farm, respectively). The age of the does varied from 8-50 months with a kidding number between 1 and 7 (Table 1). Farm owners were interviewed on the farm using a questionnaire to collect data concerning herding and feeding practices as well as to assess the reproductive performance in term of age at the first mating, age at the first kidding, kidding number, and kidding interval from the beginning to the fifth birth.

To assess the mineral and health status, 3-4 mL of blood samples were collected from the jugular vein of female goats using $10-\mathrm{mL}$ disposable syringes. The samples were immediately transferred to heparinized tubes on ice and homogenized to avoid clotting. Analysis of hematology, total protein, and minerals $(\mathrm{Ca}$, $\mathrm{P}, \mathrm{Mg}$ ) for the samples was performed at the Chemical Laboratory of National Veterinary Service Institute in Baso, Bukittinggi, West Sumatra, Indonesia. The hematological parameters measured included: hemoglobin concentration (HGB), hematocrit (HCT), total red blood cell count (RBC), mean corpuscular volume (MCV), mean corpuscular hemoglobin $(\mathrm{MCH})$, mean corpuscular $\mathrm{Hb}$ concentration (MCHC), total white blood cell count (WBC), lymphocyte count (LYM), and monocyte count (MONO).

\section{Forage and Feed Sampling Procedures and Analysis}

During the survey, samples of the plant, rice bran, and chopped sago stalk which were consumed by grazing or fed to Kacang goats, were taken to analyze dry matter (DM), crude protein (CP), and mineral contents. Plant samples were collected from three different grazing areas in which Kacang goats were frequently tethered, i.e. coconut plantations, banana plantations, and idle land. Grazing areas were located in three different villages as a mean of replication, such that a total of nine grazing areas were sampled. Forage sampling was conducted by following and observing tethered Kacang goats during browsing or grazing in the sampling sites before aerial portions of plants in this area were cut with a stainless steel knife. These procedures were repeated in three tethered posting points for each selected sampling site. The individual samples were placed in different plastic bags and weighed before chopping and mixing with the same species taken from the same grazing areas. From three representatives of grazing areas, $150 \mathrm{~g}$ samples were taken for each species for a total of 21 samples (7 plant species and 3 grazing areas as replicates).

Rice bran samples were collected from a rice mill at the study site. Sago stalk samples were taken from a goat farmer who commonly uses chopped sago stalk in goat feed. The representative samples were then dried in a forced draught oven at $60{ }^{\circ} \mathrm{C}$ for 48 hours and ground into meal form before analysis of $\mathrm{DM}, \mathrm{CP}$, and miner- 
als ( $\mathrm{Ca}, \mathrm{P}, \mathrm{Mg}, \mathrm{Fe}, \mathrm{Mn}, \mathrm{Cu}$, and $\mathrm{Zn}$ ). $\mathrm{DM}$ and $\mathrm{CP}$ were determined using proximate procedures (AOAC, 2005). Samples for mineral analysis were prepared by using a wet digestion method with concentrated sulfuric acid and hydrogen peroxide. The mineral concentration was determined using a BUXX2000 atomic absorption spectrophotometer. The results for all analyses were reported on a DM basis.

\section{Mineral Formulation and Preparation}

Mineral feed was formulated using the locally available materials: Bukit Kamang's stone powder, roasted fresh-water mussel-shell meal, and bone char meal. These materials were mixed with dicalcium phosphate and iodized table salt, and then enriched with micronutrients $\mathrm{Zn}$ and $\mathrm{Cu}\left(\mathrm{ZnSO}_{4} \cdot 7 \mathrm{H}_{2} \mathrm{O}\right.$ and $\left.\mathrm{CuSO}_{4} \cdot 5 \mathrm{H}_{2} \mathrm{O}\right)$ and a commercial mineral mixture (Ultra-Mineral ${ }^{\circledR}$, Eka Farma, Semarang, Indonesia) to produce a complete local mineral formula. The $\mathrm{Ca}, \mathrm{P}, \mathrm{Mg}, \mathrm{Na}, \mathrm{Fe}, \mathrm{Zn}, \mathrm{Cu}$, and $\mathrm{Mn}$ contents of the raw materials were analyzed using an atomic absorption spectrophotometer (AAS, 1980). The commercial mineral mixture was composed of $\mathrm{CaCO}_{3}(50 \%)$, phosphorus $(25 \%)$, manganese $(0.35 \%)$, iodine $(0.20 \%)$, potassium $(0.1 \%)$, copper $(0.15 \%)$, sodium chloride $(23.05 \%)$, iron $(0.8 \%)$, zinc $(0.2 \%)$, and magnesium $(0.15 \%)$.

The mineral concentration in the formula would complement the mineral deficiencies of forage, rice bran, and chopped sago stalk offered to Kacang goats at the study sites and to meet the 2007 NRC standards for mineral supplements for goats. The formulas were prepared in two different forms, meal and block lick forms. The block licks were prepared manually after the addition of limestone and cement as adhesive materials. The mineral composition of the formulas was: Ca: 20.921.7\%, P: 4.6-4.7\%, Mg: 3.6-5.4\%, salt: $25 \%$, Fe: 0.9-1\%, Zn: 38-39, Cu: 26-27, and Mn: 19-33 ppm. The minimum concentrations of $\mathrm{Ca}, \mathrm{P}, \mathrm{Mg}$, salt, $\mathrm{Zn}, \mathrm{Fe}, \mathrm{Cu}$, and $\mathrm{Mn}$ in the commercial mineral mixture were $16 \%, 9 \%, 4 \%$, 22\%, 30 ppm, 30 ppm, 8 ppm, and 10 ppm, respectively (Pandey et al., 2017).

\section{On-Farm Feeding Trial}

A feeding trial was carried out on a small Kacang goat farm located in Kaluat Village, Pariaman City, West Sumatra. In this trial, 15 young female Kacang goats, aged between 6 and 8 months with an average initial body weight of $8.44 \pm 1.78 \mathrm{~kg}$, were used. The animals were selected from different farms and dewormed orally using $5 \mathrm{mmg} / \mathrm{kg}$ BW fenbendazole suspension (Romindo Primavetcom) before the study. The experimental goats were divided into three groups $(n=5)$, stratified by body weight as replication and randomly assigned into either feed without supplement $(\mathrm{P} 0, \mathrm{n}=5)$, mineral mixed with feed $(\mathrm{P} 1, \mathrm{n}=5)$, or mineral block $(\mathrm{P} 2$, $\mathrm{n}=5$ ).

The animals were housed individually in $1.00 \mathrm{~m} \mathrm{x}$ $0.80 \mathrm{~m}$ pens, 0.70 above the ground, that had bambooslatted floors and sago-palm leaf roofs. The pens were equipped with feeding and drinking facilities. Each goat had a collar with an attached rope that was tethered to sites around the farm, crop plantations, and idle land, between noon and the late afternoon. Two bucks were herded together for natural mating. All goats were also supplied forage feed and concentrates in the pens. Forage in fresh form was offered twice daily, in the morning and the afternoon, between 2.5 and $3 \mathrm{~kg} / \mathrm{head} /$ day. Concentrates comprising mixtures of chopped sago stalk and lower-grade rice bran at a 4:1 ratio up to $500 \mathrm{~g} /$ head/d were offered only in the afternoon after grazing. The mineral in meal form was fed up to $15 \mathrm{~g} / \mathrm{head} / \mathrm{d}$ by mixing with concentrate (Mude et al., 2010), whereas the block mineral was placed in special wooden boxes that were available for goats to lick while confined in the pens.

The farm feeding trial lasted for 16 weeks, from July to November 2018. The goats were acclimated for 14 days until the consumption of mineral block reached approximately $15 \mathrm{~g} /$ head/day. Parameters measured included: body weight, block mineral intake, and blood hematological and biochemical values. The body weight of each goat was measured weekly in the morning on an empty stomach. Mineral block intake was measured by weighing the block before and after feeding. The average block mineral intake during the 16 weeks trial was $11.7 \mathrm{~g} /$ head/day. Pregnancy was detected by observing mating behavior and physical body changes. Once a month, all animals were scanned using an ultrasound scanner (Sonofarm mini, Draminski Ultrasound Scanner) to detect pregnancy. The pregnancy tests were repeated one month after the end of the feeding trial $\left(5^{\text {th }}\right.$ month).

At the end of week 16, blood samples were collected from the jugular vein of all goats using $10-\mathrm{mL}$ disposable syringes to measure hematology and serum chemistry. About 3-4 mL of blood was immediately transferred into tubes containing ethylenediamine tetra acetic acid (EDTA) and homogenized to avoid clotting. These samples were used for hematological analysis, which was performed on the day of collection using a Medonic Veterinary Hematology analyzer (Medonic CA 620; Medonic, Sweden).

The remaining blood samples were transferred to vacutainer tubes for serum separation by centrifugation at 3,000 rpm (LMC-3000, Grant Instrument, UK) for 20 min. The serum was collected in sterile vials and preserved at $-20^{\circ} \mathrm{C}$ until analysis of total protein, minerals, and progesterone concentrations. Concentrations of $\mathrm{Ca}$, $\mathrm{Mg}, \mathrm{P}, \mathrm{Fe}, \mathrm{Cu}, \mathrm{Mn}$, and $\mathrm{Zn}$ in serum were determined using AAS. Serum progesterone concentrations were measured using an ELISA kit (Monobind, Lilac). Blood sample preparation and analyses were carried out at the Chemical Laboratory of National Veterinary Service Institute in Baso, Bukittinggi, West Sumatra, Indonesia.

\section{Statistical Analysis}

The data obtained from the field survey were expressed as means and standard deviations (mean \pm S.D.). Data for DM, CP, and mineral composition of forages were statistically analyzed using analyses of variance (ANOVA) in a completely randomized design with 
seven different plant species collected in three different locations as replication. Data for body weight, hematology parameters, total blood protein, and blood minerals from the field trial were analyzed in a block randomized design with three treatments of mineral supplementation and five goats of different body weights as replications. Duncan's Multiple Range (DMRT) was applied to separate means. Differences were considered significant at $\mathrm{p}<0.05$ (Steel et al., 1997).

\section{RESULTS}

\section{Reproductive Performances of Tethered Kacang Goat Does}

Results of the field survey for reproduction performance and mineral, protein, and hematology parameters of Kacang goat does raised in small farms using a tethered system are shown in Table 1 . The reproductive performances varied widely. The age of puberty (or first mating) ranged between 5 and 9 months and first kidding was between 12 and 23 months. There was a prolonged kidding interval between the first and the second birth that was between 7 and 17 months. The 7-12 months parturition interval that separated the second and fifth births was relatively normal, whereas the reproduction rate progressively increased with the advancing parturition. Blood mineral and hematological profiles indicated that Kacang goat does were malnourished and in poor health conditions. The values for mineral ( $\mathrm{Ca}, \mathrm{P}$, and $\mathrm{Mg}$ ) and erythrocyte indices (hemoglobin and hematocrit) were below the normal range,

Table 1. Flock size, structure, and reproductive performances of female Kacang goats reared under a tethering system

\begin{tabular}{|c|c|c|}
\hline Parameter & Range & Mean \\
\hline Population number (head/farm) & $2-23$ & $7.06 \pm 4.21$ \\
\hline Doe & $1-6$ & $3.12 \pm 1.78$ \\
\hline Buck & $0-12$ & $2.95 \pm 2.48$ \\
\hline Young doe & $0-2$ & $1.14 \pm 0.38$ \\
\hline Kids & $0-5$ & $2.31 \pm 1.16$ \\
\hline Age of doe (month) & $8-50$ & $27.26 \pm 14.54$ \\
\hline Kidding number & $1-7$ & $2.44 \pm 1.50$ \\
\hline \multicolumn{3}{|l|}{$\begin{array}{l}\text { Reproductive performances of does } \\
\text { (month) }\end{array}$} \\
\hline Age at first mating & $5-9$ & $6.08 \pm 0.56$ \\
\hline Age at first kidding & $12-23$ & $12.39 \pm 1.26$ \\
\hline Mating interval after first kidding & $0.5-3$ & $1.21 \pm 0.50$ \\
\hline $\begin{array}{l}\text { Kidding interval of parity } 1 \text { and } \\
\text { parity } 2\end{array}$ & $7-17$ & $7.49 \pm 1.64$ \\
\hline Mating after parity 2 & $1-10$ & $1.58 \pm 1.43$ \\
\hline $\begin{array}{l}\text { Kidding interval between parity } 2 \\
\text { and parity } 3\end{array}$ & $7-12$ & $7.83 \pm 1.36$ \\
\hline Mating after parity 3 & $0.5-3$ & $1.34 \pm 0.68$ \\
\hline $\begin{array}{l}\text { Kidding interval between parity } 3 \\
\text { and parity } 4\end{array}$ & $7-9$ & $7.74 \pm 1.24$ \\
\hline Mating after parity 4 & $1-3$ & $1.67 \pm 0.62$ \\
\hline $\begin{array}{l}\text { Kidding interval between birth } 4 \\
\text { and birth } 5\end{array}$ & $7-9$ & $7.73 \pm 0.59$ \\
\hline
\end{tabular}

whereas WBC, lymphocyte, and monocyte counts were much higher than the normal range (Table 2).

\section{Dry Matter, Crude Protein, and Mineral Composition of Feed}

Only seven major forage species were consumed by the tethered goats in the field study (Table 3). These species were dominated by shade-tolerant species comprising three native grasses (A. compressus, $C$. rotundus, and $P$. conjugatum), three broadleaves (A. gangetica, $A$. conyzoides, and $S$. jamaicensis) and a fern ( $P$. vulgareae). The DM contents of the forages varied from 11.7 to $23.5 \%$. Of the species considered, five (C. rotundus, $S$. jamaicensis, A. gangetica, P. conjugatum, and A. conyzoides) had DM below $20 \%$. The CP contents varied from $14.0-20.9 \%$ DM. Two plant species, $A$. conyzoides and A. gangetica, had considerably high CP values of $20.9 \%$ and $19.8 \%$, respectively. The other five species (A. compresus, $C$. rotundus, $P$. conjugatum, $S$. jamaicensis, and $P$. vulgareae) had relatively high CP values of $14.0 \%-16.0 \%$. Meanwhile, rice bran and sago stalk had low $\mathrm{CP}$ content (5.0\% and $8.4 \%$, respectively; Table 3 ).

The calcium contents of the feed varied from 1.7-9.7 $\mathrm{g} / \mathrm{kg}$ DM. A. conyzoides had the highest Ca concentration, i.e. $9.7 \mathrm{~g} / \mathrm{kg}$ DM. S. jamaicensis and P. vularea also had considerably high Ca concentrations, i.e. 5.4 and 4.1 $\mathrm{g} / \mathrm{kg}$ DM, respectively. Meanwhile, A. compresus, C. rotundus, $P$. conjugatum, and $A$. gangetica had low calcium concentrations. A. gangetica had the highest $\mathrm{Mg}$ content (7.9 g/kg DM), followed by A. conyzoides $(5.1 \mathrm{~g} / \mathrm{kg} \mathrm{DM})$ and $P$. vulgare $(4.6 \mathrm{~g} / \mathrm{kg} \mathrm{DM})$. Forage and local concen-

Table 2. Mineral profiles, total protein concentration, and hematology values in blood serum from female Kacang goats reared using a tethering system

\begin{tabular}{|c|c|c|}
\hline Parameter & Mean & $\begin{array}{l}\text { Normal } \\
\text { range* }\end{array}$ \\
\hline \multicolumn{3}{|l|}{ Macromineral (mg.dL-1) } \\
\hline Calcium & $7.71 \pm 1.13$ & $8.5-11.5$ \\
\hline Magnesium & $1.63 \pm 0.32$ & $1.8-3.2$ \\
\hline Phosphorus & $2.85 \pm 1.14$ & $3.2-6.0$ \\
\hline Total protein $\left(\mathrm{mg} \cdot \mathrm{dL}^{-1}\right)$ & $6.05 \pm 1.04$ & $6-7^{* *}$ \\
\hline \multicolumn{3}{|l|}{ Hematology } \\
\hline $\begin{array}{l}\text { Hemoglobin concentration (HGB) } \\
(\text { g.dL-1) }\end{array}$ & $6.66 \pm 2.31$ & $8.4-12.0$ \\
\hline Hematocrit (HCT) $(\%)$ & $18.83 \pm 5.76$ & $22.0-38.0$ \\
\hline Total red blood cell (RBC) $\left(\times 10^{6} \mu \mathrm{L}^{-1}\right)$ & $11.57 \pm 6.40$ & $5.0-10.0$ \\
\hline $\begin{array}{l}\text { Mean corpuscular volume (MCV) } \\
\text { (fL) }\end{array}$ & $17.36 \pm 0.68$ & $16-25$ \\
\hline $\begin{array}{l}\text { Mean corpuscular hemoglobin } \\
(\mathrm{MCH})(\mathrm{pg})\end{array}$ & $6.42 \pm 0.30$ & $6.0-6.9$ \\
\hline $\begin{array}{l}\text { Mean corpuscular Hb concentration } \\
(\mathrm{MCHC})\left(\mathrm{g} \cdot \mathrm{dL}^{-1}\right)\end{array}$ & $36.98 \pm 1.49$ & $30.0-36.0$ \\
\hline $\begin{array}{l}\text { Total white blood cell count (WBC) } \\
\left(\times 10^{3} \mu \mathrm{L}^{-1}\right)\end{array}$ & $21.24 \pm 5.55$ & $3.0-13.0$ \\
\hline Lymphocyte count (LYM) $\left(x 10^{3} \cdot \mu \mathrm{L}^{-1}\right)$ & $10.16 \pm 2.85$ & $2.0-9.0$ \\
\hline Monocyte count (MONO) $\left(x 10^{3} \cdot \mu \mathrm{L}^{-1}\right)$ & $1.64 \pm 0.46$ & $0.0-1.0$ \\
\hline
\end{tabular}

Note: ${ }^{*}$ From Feldman et al. (2002); ${ }^{* *}$ From http://goat-link.co 
Table 3. Dry matter, crude protein, and mineral composition of forage, rice bran, and sago stalk consumed by tethered Kacang goats

\begin{tabular}{|c|c|c|c|c|c|c|c|c|}
\hline \multirow{2}{*}{ Forage species } & \multirow{2}{*}{$\mathrm{DM}(\% \mathrm{FW})$} & \multirow{2}{*}{$\begin{array}{l}\text { Crude protein } \\
\quad(\% \mathrm{DM})\end{array}$} & \multicolumn{3}{|c|}{ Macro minerals (g/kg DM) } & \multicolumn{3}{|c|}{ Trace minerals (mg/kg DM) } \\
\hline & & & $\mathrm{Ca}$ & $\mathrm{P}$ & $\mathrm{Mg}$ & $\mathrm{Mn}$ & $\mathrm{Cu}$ & $\mathrm{Zn}$ \\
\hline Axonopus compresus & $21.25 \pm 1.98^{\mathrm{ab}}$ & $14.19 \pm 0.33^{\mathrm{b}}$ & $1.73 \pm 0.12^{c}$ & $1.92 \pm 0.79$ & $1.92 \pm 0.75^{c}$ & $93.44 \pm 27.27 \mathrm{~b}$ & $31.55 \pm 35.06^{\mathrm{b}}$ & $40.44 \pm 5.58^{\mathrm{b}}$ \\
\hline Cyperus rotundus & $18.05 \pm 1.10^{\mathrm{b}}$ & $15.56 \pm 0.67^{b}$ & $3.21 \pm 0.36^{\mathrm{bc}}$ & $2.57 \pm 0.05$ & $1.34 \pm 0.26^{c}$ & $127.04 \pm 3.53^{\mathrm{a}}$ & $14.66 \pm 3.58^{c}$ & $60.83 \pm 6.38^{a}$ \\
\hline Cynodon dactylon & $13.79 \pm 0.32^{\mathrm{cd}}$ & $15.34 \pm 0.50^{\mathrm{b}}$ & $3.00 \pm 0.54^{\mathrm{bc}}$ & $2.28 \pm 0.93$ & $2.91 \pm 0.11^{\mathrm{bc}}$ & $104.64 \pm 11.69^{\mathrm{ab}}$ & $30.90 \pm 15.38^{\mathrm{b}}$ & $43.99 \pm 2.02^{b}$ \\
\hline Asystasia gangetica & $11.72 \pm 0.87^{\mathrm{d}}$ & $19.79 \pm 1.30^{\mathrm{a}}$ & $3.92 \pm 1.08^{\mathrm{bc}}$ & $2.10 \pm 0.25$ & $7.99 \pm 0.48^{\mathrm{a}}$ & $101.29 \pm 31.94^{\mathrm{ab}}$ & $12.91 \pm 0.58^{c}$ & $49.49 \pm 13.34^{\mathrm{b}}$ \\
\hline Ageratum conyzoides & $14.23 \pm 2.10^{c}$ & $20.91 \pm 0.73^{\mathrm{a}}$ & $9.73 \pm 0.60^{\mathrm{a}}$ & $2.53 \pm 0.02$ & $5.10 \pm 1.76^{\mathrm{b}}$ & $91.68 \pm 15.55^{\mathrm{b}}$ & $73.39 \pm 20.27 \mathrm{a}$ & $53.53 \pm 4.59^{\mathrm{ab}}$ \\
\hline $\begin{array}{l}\text { Stachytarpheta } \\
\text { jamaicensis }\end{array}$ & $18.43 \pm 2.06^{b}$ & $15.98 \pm 0.73^{b}$ & $5.41 \pm 0.86^{\mathrm{b}}$ & $1.49 \pm 0.49$ & $2.69 \pm 0.91^{\mathrm{bc}}$ & $52.47 \pm 21.18^{c}$ & $25.37 \pm 11.72^{\mathrm{b}}$ & $56.08 \pm 11.72^{\mathrm{ab}}$ \\
\hline Polypodium vulgarea & $23.45 \pm 2.09^{a}$ & $13.97 \pm 0.33^{\mathrm{b}}$ & $4.14 \pm 0.58^{\mathrm{b}}$ & $1.99 \pm 0.08$ & $4.60 \pm 1.31^{\mathrm{b}}$ & $33.59 \pm 27.67 \mathrm{c}$ & $24.56 \pm 10.68^{b}$ & $31.45 \pm 7.28^{c}$ \\
\hline Sago stalk & 45.18 & 5.02 & 0.94 & 0.16 & 0.22 & 117.55 & 0.00 & 18.67 \\
\hline Rice bran & 91.77 & 8.42 & 0.21 & 1.04 & 1.45 & 109.86 & 0.00 & 26.58 \\
\hline
\end{tabular}

Note: Means in the same column with different superscripts differ significantly ( $<<0.05)$ (just for forages); FW: fresh weight.

trates consumed by Kacang goats were generally poor in $\mathrm{p}$ with values ranging from 1.5 to $2.6 \mathrm{~g} / \mathrm{kg}$ DM (Table 3).

The amount of Mn varied from 33.6 to $127.0 \mathrm{mg} / \mathrm{kg}$ DM. Three plant species, C. rotundus, C. dactylon, and $A$. gangetica, contained relatively high amounts of $\mathrm{Mn}$ that were $\geq 100 \mathrm{mg} / \mathrm{kg} \mathrm{DM}$. The Cu content varied from 14.7 to $73.4 \mathrm{mg} / \mathrm{kg} \mathrm{DM}$, with $A$. conyzoides having the highest content. The concentrations of $\mathrm{Zn}$ ranged from 31.5 to $60.8 \mathrm{mg} / \mathrm{kg}$ DM. In general, forages contained considerably high amounts of micronutrients compared to standard dietary requirements for goats, whereas sago stalks and rice bran contained relatively high amounts of $\mathrm{Mn}$, but not $\mathrm{Zn}, \mathrm{Cu}$, and macronutrients (Table 3).

\section{Effects of Mineral Supplementation}

The effects of mineral supplementation on body weight, blood progesterone concentrations, and pregnancy status of Kacang goats were assessed (Table 4). Goats supplemented with local minerals in meal and block form (P1 and P2, respectively) tended to become pregnant sooner, typically between the first and the third months. Only one goat in the control group (P0) become pregnant in the first month, whereas the other four goats become pregnant between the third and the fifth months. The data for pregnancy rates were supported by the data for body weight and blood progesterone concentrations. Goats supplemented with local minerals had higher final body weights and blood progesterone concentrations compared to goats in the non-supplemented control group, although this difference was not statistically significant $(\mathrm{p}>0.05)$.

The mean values of mineral concentration and hematological parameters for goats fed control and supplemented feed showed no statistically significant difference ( $p>0.05$; Table 5). For both the control and supplemented groups, blood calcium, hemoglobin (HGB), and hematocrit (HCT) was lower than the normal range, whereas the WBC, lymphocyte, and monocyte counts were higher than the normal range. The total proteins for the three experimental groups were between 6.05 and $6.28 \mathrm{~g} / \mathrm{dl}$, which were within the normal range values of 6-7 g/dl. The mineral supplementation groups (P1 and P2) showed the higher concentrations of serum minerals $(\mathrm{Ca}, \mathrm{Mg}, \mathrm{Fe}$, and $\mathrm{Zn}$ ) as well as higher
Table 4. Pregnancy status of female Kacang goats supplemented with mineral formulas in the farm feeding trial

\begin{tabular}{lccc}
\hline $\begin{array}{l}\text { Experimental } \\
\text { treatment }\end{array}$ & $\begin{array}{c}\text { Goat } \\
\text { number }\end{array}$ & $\begin{array}{c}\text { Pregnant } \\
\text { status }\end{array}$ & $\begin{array}{c}\text { Month pregnancy } \\
\text { detected }\end{array}$ \\
\hline P0: Control & 1 & + & 4 \\
(no mineral & 2 & + & 4 \\
supplement) & 3 & + & 5 \\
& 4 & + & 1 \\
& 5 & + & 3 \\
P1: Supplemented & 1 & + & 2 \\
with mineral in & 2 & + & 3 \\
meal form & 3 & + & 4 \\
& 4 & + & 3 \\
& 5 & + & 3 \\
P2: Supplemented & 1 & + & 1 \\
with mineral in & 2 & + & 4 \\
block form & 3 & + & 1 \\
& 4 & + & 4 \\
& 5 & + & 2 \\
\hline
\end{tabular}

HGB, HCT, and red blood cell counts than the control group (P0). However, there was no statistically significant difference. The highest mean values for minerals $(\mathrm{Ca}, \mathrm{Mg}$, and $\mathrm{Fe}$ ), HGB, and RBCs were seen in goats supplemented with local minerals in meal form (P1).

Meanwhile, goats supplemented with local minerals in block form (P2) had the highest final body weight $(10.58 \mathrm{~kg} / \mathrm{head})$ and blood progesterone concentration $(4.80 \mu \mathrm{g} / \mathrm{mL})$ (Table 5) as well as total protein and $\mathrm{P}$ concentrations in the blood (Table 5). Goats given block mineral supplementation (P2) also tended to become pregnant sooner than did those supplemented with minerals in meal form (P1) (Table 4).

\section{DISCUSSION}

The outcomes of rearing practices for Kacang goats in the Pariaman region of Indonesia were characterized by measuring biological and reproductive parameters 
Table 5. Blood mineral concentration, total protein, progesterone, hematological parameters and body weight of female Kacang goats supplemented with mineral formulas in the farm feeding trial

\begin{tabular}{|c|c|c|c|c|}
\hline \multirow[b]{2}{*}{ Parameter } & \multicolumn{3}{|c|}{ Treatments } & \multirow[b]{2}{*}{ Normal range } \\
\hline & $\begin{array}{l}\text { Control (no mineral } \\
\text { supplement) }(\mathrm{P} 0)\end{array}$ & $\begin{array}{c}\text { Supplemented with } \\
\text { mineral in meal form (P1) }\end{array}$ & $\begin{array}{l}\text { Supplemented with } \\
\text { block mineral (P2) }\end{array}$ & \\
\hline \multicolumn{5}{|l|}{ Macromineral (mg.dL $\left.\mathrm{dL}^{-1}\right)$} \\
\hline $\mathrm{Ca}$ & $6.78 \pm 1.66$ & $7.42 \pm 0.81$ & $6.53 \pm 0.93$ & $8.5-11.5$ \\
\hline $\mathrm{Mg}$ & $2.64 \pm 0.59$ & $2.88 \pm 0.43$ & $2.86 \pm 0.51$ & $1.8-3.2$ \\
\hline $\mathrm{P}$ & $2.34 \pm 0.71$ & $2.72 \pm 1.06$ & $3.36 \pm 0.89$ & $3.2-6.0$ \\
\hline \multicolumn{5}{|l|}{ Micromineral (ppm)* } \\
\hline $\mathrm{Fe}$ & $1.30 \pm 1.08$ & $2.67 \pm 1.57$ & $1.60 \pm 0.69$ & $0.89-2.53$ \\
\hline $\mathrm{Cu}$ & $0.67 \pm 0.17$ & $0.62 \pm 0.13$ & $0.59 \pm 0.05$ & N/A \\
\hline $\mathrm{Zn}$ & $0.37 \pm 0.16$ & $0.95 \pm 1.23$ & $0.28 \pm 0.23$ & $0.70-1.30$ \\
\hline Total protein $\left(\mathrm{mg} \mathrm{dL}^{-1}\right)$ & $6.26 \pm 0.80$ & $6.00 \pm 0.74$ & $6.40 \pm 1.05$ & $6-7^{*}$ \\
\hline Hematology & & & & Normal range $^{* *}$ \\
\hline HGB (g.dL $\left.{ }^{-1}\right)$ & $6.24 \pm 0.87$ & $7.40 \pm 1.60$ & $6.98 \pm 0.99$ & 8.4-12.0 \\
\hline $\mathrm{HCT}(\%)$ & $17.18 \pm 2.68$ & $20.26 \pm 4.70$ & $19.06 \pm 2.86$ & $22.0-38.0$ \\
\hline $\mathrm{RBC}\left(x 10^{6} \mu \mathrm{L}^{-1}\right)$ & $9.79 \pm 1.52$ & $11.96 \pm 2.35$ & $11.12 \pm 1.85$ & $5.0-10.0$ \\
\hline $\operatorname{MCV}(\mathrm{fL})$ & $17.54 \pm 0.48$ & $16.84 \pm 0.68$ & $17.18 \pm 0.79$ & $16-25$ \\
\hline $\mathrm{MCH}(\mathrm{pg})$ & $6.38 \pm 0.23$ & $6.18 \pm 0.16$ & $6.58 \pm 0.64$ & $6.0-6.9$ \\
\hline $\mathrm{MCHC}\left(\mathrm{g} \cdot \mathrm{dL}^{-1}\right)$ & $36.60 \pm 0.92$ & $36.70 \pm 1.13$ & $36.74 \pm 0.40$ & $30.0-36.0$ \\
\hline $\mathrm{WBC}\left(\times 10^{3} \mu \mathrm{L}^{-1}\right)$ & $15.86 \pm 5.55$ & $20.04 \pm 1.40$ & $22.32 \pm 1.33$ & $3.0-13.0$ \\
\hline $\operatorname{LYM}\left(x 10^{3} \cdot \mu \mathrm{L}^{-1}\right)$ & $7.86 \pm 3.39$ & $9.20 \pm 1.56$ & $10.12 \pm 1.31$ & $2.0-9.0$ \\
\hline MONO (x10³. $\mu \mathrm{L}-1)$ & $1.04 \pm 0.23$ & $1.34 \pm 0.21$ & $1.52 \pm 0.16$ & $0.0-1.0$ \\
\hline Progesterone (ng/mL) & $3.84 \pm 5.50$ & $1.92 \pm 2.73$ & $4.80 \pm 5.71$ & \\
\hline Initial body weight (kg) & $8.54 \pm 1.57$ & $8.44 \pm 1.75$ & $8.68 \pm 1.86$ & \\
\hline Final body weight (kg) & $9.62 \pm 1.22$ & $10.32 \pm 2.10$ & $10.58 \pm 0.82$ & \\
\hline
\end{tabular}

Note: ${ }^{*}$ From http://goat-link.co; ${ }^{* *}$ From Feldman et al. (2002); N/A not available.

of goats tethered for grazing on wild vegetation grown under tree crops on plantations or idle land near homesteads. The low input and output tethering system may become a more common practice for goat production in regions where land scarcity and forage production are limiting factors. Patra et al. (2008) noted that tethering could offer a production advantage over free grazing in term of reduced amounts of energy needed for the same grazing time. According to the goat farmers, tethering was a favored practice to avoid effects of adverse weather (e.g., rain, acute sunshine, and high temperature), as well as to cope with scarcity of pasture and labor shortages. However, the limited availability of family labor and pressures from the other farming activities often prevent farmers from moving their goats frequently, which can lead to a fluctuation in feed intake and irregular tethering. Goats should be moved as frequently as possible to ensure good nutrition. However, such movement was often impractical when large numbers of goats were tethered. Moreover, some farmers had difficulty in finding free grazing opportunities in area that lacked farm fields or where land ownership was unclear. Tethering systems can also limit the ability of goat to graze optimally and allows access only to forage that is available within the radius of the rope. Goats tend to selectively consume younger parts of plants, which results in limited variations in forage preferences and low DM intake. Here, wild vegetation consumed by goats contained relatively high levels (14\%-21\% in DM) of CP in DM (Table 3) and goats indeed met their protein requirements as was reflected by the normal protein concentration in the blood.

The high variability in sexual maturity, first kidding, and kidding interval between the first and the second parity observed in this study could be attributed to the fluctuating or inadequate feed intake due to the limited grazing area, irregular tethering schedules or differences in feeding practices and flock sizes. Tethered Kacang goats can suffer from anemia and health problems presumably due to deficiencies in micronutrients as were indicated by erythrocyte indices (hemoglobin and hematocrit) in the blood samples (Table 2). In addition to $\mathrm{Fe}$ and $\mathrm{Cu}$, the $\mathrm{Zn}$ plays an important role in hemoglobin synthesis (Dangi et al., 2011). In general, forage and agro-industrial by-products consumed by the tethered Kacang goats have poor macromineral contents. The use of rice bran and chopped sago stalks also provides low nutrition values for goats due to their high fiber content and small amounts of protein and minerals. The goats in this study might also be affected by various parasitic infections and the other diseases as were indicated by the much higher WBC, lymphocyte, and monocyte counts relative to the normal ranges. The high temperature and humidity in the study region favor the development and survival of parasite eggs, larvae, cysts, and oocysts in the grazing areas in crop plantations and idle lands. Indeed, Jittapalapong et al. (2012) reported that about $94 \%$ of goats reared semi- 
intensively for meat in small farms in the Satun Province of southern Thailand were positive for helminthic or protozoal parasites. In this study, farmers reported that their goats were also affected by diarrhea, bloating, scabies (ectoparasites), and fever.

The results of the feeding trial demonstrated that mineral supplementation could benefit nutritional status, health, and reproductive performances of tethered female Kacang goats as were indicated by the improved blood hematological values, blood mineral profiles, and the occurrence of pregnancy at younger ages. The erythrocyte indices (hemoglobin, hematocrit, red blood cell) of goats supplemented with local minerals were slightly higher than those of the control group. The serum mineral profiles were also slightly increased in the supplemented groups. These results suggested that mineral supplementation could stimulate ovarian activity and promote conception as was indicated by the increased blood progesterone concentrations that directly reflect the activity of corpus luteum (Barui et al., 2015). $\mathrm{Cu}$ and $\mathrm{Zn}$ contribute to progesterone production by luteal cells by regulating superoxide dismutase activity (Sales et al., 2011). Zinc plays an essential role in sexual development and is also involved in reorganization of ovarian follicles that produce progesterone (Yatoo et al., 2013). Reproductive events (e.g., estrus, pregnancy, and lactation) and particularly the onset of estrus in females are affected by zinc (Amin et al., 2016). Iron is also essential for optimal ovarian activity (Qian et al., 2001). Yatoo et al. (2016) reported positive correlations between the levels of $\mathrm{Fe}, \mathrm{Zn}$, and $\mathrm{Mn}$ and progesterone in heifers. In contrast, macronutrients $\mathrm{Ca}, \mathrm{P}$, and $\mathrm{Mg}$ alone typically do not directly affect the reproductive status of animals, even though the disturbances in Ca-P-Mg homeostasis can have some effects on reproduction (Amin et al., 2016; Ullah et al., 2010).

The positive effect of mineral supplements on ruminant nutritional status and reproduction has been reported in other studies. Niaz et al. (2017) found that in Ganjam goats, supplementation with $100 \mathrm{~g}$ of concentrate together with $0.5 \mathrm{~g}$ of an area-specific mineral mixture significantly increased serum mineral concentrations in treated groups, resulting in improved reproductive performance. In a study by Mude et al. (2010), pregnant does orally supplemented with up to $15 \mathrm{~g} / \mathrm{d}$ of mineral had increased survival of kids and reduced the frequency of post-partum complications during kidding. Tiwari et al. (2014) reported a superior daily gain in male goats could be obtained by supplementation of the basal diet with $15 \mathrm{~g}$ mineral mixture/goat/day. Godara et al. (2015) revealed that area-specific mineral supplementation improved plasma biochemical profiles and enhanced early maturity in Black Bengal goats. Beneficial effects of mineral supplementation on nutritional status and reproductive performance have been also reported in large ruminants. Satapathy et al. (2016) noted that supplementation with an area-specific mineral mixture @ $50 \mathrm{~g} / \mathrm{d} /$ animal improved the blood $\mathrm{Hb}$ concentration and reproductive health of cross-bred cows in Kakatpu Block, India. Solda et al. (2017) reported that pregnant dairy cows supplemented with a mineral blend com- prising selenium, copper, magnesium, phosphorus, and potassium had a higher concentration of total erythrocytes relative to non-supplemented cows.

In this study, we also demonstrated the beneficial effects of local mineral supplementation, mainly when the minerals were offered in block lick form, on reproductive performances of tethered female Kacang goats. The animals given mineral blocks had better body condition and appeared to be healthier than those given feed supplemented with minerals in meal forms. Our findings are consistent with those of a study by Gouda et al. (2017) showing that minerals have both direct and indirect relationships with reproductive health of animals. The advantage of mineral supplementation given in blocks over that of adding minerals to feed concentrates is that minerals are consumed more slowly. Minerals in block form ensure an adequate mineral supply to the rumen and nutritional requirements of rumen microorganisms that can enhance performance of host animals. Feed blocks are also considered to be good supplements for poor-quality diets, as they allow a balanced and synchronized supply of nutrients (i.e., energy, N, minerals, and vitamins) that are tailored to ruminants (Gasmi-Boubaker et al., 2006). Wang et al. (2016) reported that mineral block supplementation for Tibetan sheep significantly improved serum levels of $\mathrm{Mn}, \mathrm{Fe}$, and Se and had positive effects on the activity of antioxidant defense systems and immune-related parameters.

Overall, the present study demonstrated that the reproductive performance of female Kacang goats raised using tethering systems could be optimized by supplying sufficient amounts of minerals. Our findings form a basis for improving the nutritional status of tethered goats, particularly when the quality and availability of forages and feed concentrates are limited. Results from this study contribute relevant information concerning the importance of minerals in reproduction and can be used to prevent and manage diseases associated with mineral deficiency in ruminants raised in small farms. These results will be of interest to researchers, goat farmers, and government agencies, by presenting methods to improve local goat productivity through the use of locally available minerals.

\section{CONCLUSION}

Suboptimal reproductive performance of Kacang goats raised using tethering systems is closely related to the inadequate feed intake and nutritional deficiency, which highlight the need for mineral supplementation. The nutritional status, health, and pregnancy of tethered female Kacang goats were enhanced by mineral supplementation. Local minerals offered in block lick form had a better effect on reproductive and biochemical parameters than did mineral in meal form that was mixed with feed concentrates. These results suggest that the better reproductive performance of supplemented goats can be associated with improved nutritional and health status. The findings of this study can guide the use of mineral supplements made using 
locally available materials to improve nutritional status and reproductive efficiency of tethered female Kacang goats.

\section{CONFLICT OF INTEREST}

The authors declare that there is no conflict of interest with any financial, personal, or other relationships with other people or organizations related to the material discussed in this manuscript.

\section{ACKNOWLEDGEMENT}

This study is part of the project entitled "Design of Mineral Formulas for Nutritional Improvement of Goat's Feed Based on Forages and Agroindustry Byproducts" (Contract No: 46/UN.16.17/PP.RGB/ LPPM/2018) which was financially supported by the Ministry of Research, Technology, and Higher Education of the Republic of Indonesia. The authors gratefully acknowledge the co-operation and technical support of the Veterinary Research Center, Bukittinggi, West Sumatra for this study.

\section{REFERENCES}

Akhtar, M.S., A.A. Farooq, L.A. Lodhi, S. Muhammad, M.M. Ayaz, M. H. Lashari, S. Murtaza, I. Hussain, M. Irshad, M. Hussain, \& M.A. Raza. 2014. Studies on serum macro and micro minerals status in repeat breeder and normal cyclic Nili-Ravi buffaloes and their treatment strategies. Afr. J. Biotechnol. 13:1143-1146. https://doi.org/10.5897/ AJB12.2328

Amin, B.Y., R.S Dar, A. Ali1, J. A. Malla, \& S. Shubeena. 2016. Role of micro-nutrients in bovine reproduction. Theriogenology Insight 6: 57-65. https://doi. org/10.5958/2277-3371.2016.00008.5

AOAC. 2005. Official Methods of Analysis of AOAC International. 18th ed. Assoc. Off. Anal. Chem., Arlington.

Barui A, S. Batabyal, S. Ghosh, D. Saha, S. Chattopadhyay. 2015. Plasma mineral profiles and hormonal activities of normal cycling and repeat breeding crossbred cows: A comparative study. Vet. World 8: 42-45. https://doi. org/10.14202/vetworld.2015.42-45

Dangi, C.B.S., M. Kaur, \& M. Singh. 2011. Copper and zinc quotient in haemoglobinopathies. Biomed \& Pharm. J. 4: 165-173. https://doi.org/10.13005/bpj/276

Godara, R.S., S. Naskar, B.C. Das, A.S. Godara, M.K. Ghosh, M. Mondal \& S. A. Bhat. 2015. Effect of area specific mineral supplementation on biochemical profile in female Black Bengal goats. J. Anim. Res. 5:263-268. https://doi. org/10.5958/2277-940X.2015.00045.5

Feldman, B., J. Zink, \& N. Jain. 2002. Schalm's Veterinary Hemetology. Lippincott Williams and Wilkins, Philadelphia, PA, Baltimore, New York, London, Buenos Aires, Hong Kong, Sidney, Tokyo.

Gasmi-Boubaker, A., C. Kayouli, A. Buldgen, A. Boukary, H. Ammar, \& S. Lopez. 2006. Effect of feed block supply on the ruminal ecosystem of goats grazing shrub land in Tunisia. Anim. Feed Sci. Tech. 127: 1-12. https://doi. org/10.1016/j.anifeedsci.2005.06.010

Gouda, G., K. Sethy, R.K. Swain, S.K. Mishra, K. Behera, N.R. Debata, \& B. Mishra. 2017. Effect of area specific mineral mixture and hormonal interventions on growth, blood chemistry and mineral status of the reproductive disorders cross bred cattle. Pharma. Innov. 6: 284-286 .
Jittapalapong, S., S. Saengow, N. Pinyopanuwat, W. Chimnoi, W. Khachaeram, \& R.W. Stich. 2012. Gastrointestinal helminthic and protozoal infections of goats in Satun, Thailand. J. Trop. Med. Parasitol. 35:48-54

Khalil. 2016. Crude nutrient and mineral composition of Asystasia gangetica (L) as a predominant forage species for feeding of goats. Pakistan J. Nutr. 15:867-872. https:// doi.org/10.3923/pjn.2016.867.872

Khalil, W. Wati, F. Hidayat, \& Evitayani. 2018. Physical properties and nutritive values of shell meal derived from different shellfish species and habitats. Int. J. Poult. Sci. 17: 116-125. https://doi.org/10.3923/ijps.2018.116.125

Khalil, Reswati, Ferawati, Y.F. Kurnia, \& F. Agustin. 2017. Studies on physical characteristics, mineral composition, and nutritive value of bone meal and bone char produced from inedible cow bones. Pak. J. Nutr. 16:426-434. https:// doi.org/10.3923/pjn.2017.426.434

Khalil, M. N. Lestari, P. Sardilla, \& Hermon. 2015. The use of local mineral formulas as a feed block supplement for beef cattle fed on wild forages. Med. Pet. 38:34-41. https://doi. org/10.5398/medpet.2015.38.1.34

Khalil, B. Primasari, \& S. Anwar. 2012. Studies on physical properties of Bukit Kamangs' limestone as mineral source for laying hens. J. Indonesian Trop. Anim. Agric. 36:171179. https://doi.org/10.14710/jitaa.36.3.171-179

Mude, S.W., S.P. Waghmare, S.G. Mode, P.G. Sukare, \& S.A. Adlak. 2010. Effect of mineral supplementation on postparturient diseases in pregnant goats. Vet. World 3:109-110.

National Research Council (NRC). 2007. Nutrient Requirements of Small Ruminants: Sheep, Goats, Cervids, and New World Camelids. The National Academies Press, Washington DC.

Niaz, F., K. Sethy, R.K. Swain, K. Behera, S.K. Mishra, D.K. Karna, \& C. Mishra. 2017. Combined effect of concentrate and area specific mineral mixture supplementation on the performance of Ganjam goat in its native tract. Pharma Innov. 6: 320-323.

Pandey, V.K., M.K. Gendley, S.P. Tiwari, \& S. Prusty. 2017. Effect of supplementation of area specific mineral mixture on serum mineral status of cattle in different agro-climatic zones of Chhattisgarh state. J. Anim. Res. 7: 827-835. https://doi.org/10.5958/2277-940X.2017.00127.9

Patra, A.K., R. Puchala, G. Detweiler, L. J. Dawson, G. Animut, T. Sahlu, \& A. L. Goetsch. 2008. Tethering meat goats grazing forage of high nutritive value and low to moderate mass. Asian-Australas. J. Anim. Sci. 21: 1252-1261. https:// doi.org/10.5713/ajas.2008.60670

Qian, L.C., X.T. Zou, Z.R. Xu, \& S. Xi. 2001. Effect of various levels of iron on the reproductive performance and biochemical parameters of gestation cow. Chinese J. Vet. Sci. 21: 526-528.

Sales, J.N.S., R.V.V. Pereira, R.C. Bicalho, \& P.S. Baruselli. 2011. Effect of injectable copper, selenium, zinc and manganese on the pregnancy rate of crossbred heifers (Bos indicus $\times$ Bos taurus) synchronized for timed embryo transfer. Livest. Sci. 142: 59-62. https://doi.org/10.1016/j. livsci.2011.06.014

Sahoo, J.K., S.K. Das, K. Sethy, S. K. Mishra, R.K. Swain, P.C. Mishra, \& D. Satapathy. 2016. Effect of supplementation of mineral mixture and bypass fat on performance of crossbred cattle. J. Anim. Res. 6:611-618. https://doi. org/10.5958/2277-940X.2016.00071.1

Satapathy, D., S.K. Mishra, R.K. Swain, K. Sethy, \& G.R Sahoo. 2016. Effect of supplementation of area specific mineral mixture on performance of crossbred cows with reproductive disorders in Kakatpur Block. Indian J. Anim. Nutr. 33: 279-284. https://doi.org/10.5958/2231-6744.2016.00049.9

Soldá, N.M, P. Glombowsky, G. Campigotto, \& N. B. Bottari. 2017. Injectable mineral supplementation to transition 
period dairy cows and its effects on animal health. Comp. Clin. Patho. 26:335-342. https://doi.org/10.1007/ s00580-016-2378-y

Steel. R.G.D., J.H. Torrie, \& J.H. Dicky. 1997. Principles and Procedures of Statistics: A Biometritrical Approach. 3rd Ed. McGraw-Hill Book Co. Inc., New York, USA.

Suttle, N.F. 2010. Mineral Nutrition of Livestock. 4th Ed. Moredun Foundation. Pentland Science Park, Midlothian, UK. https://doi.org/10.1079/9781845934729.0000

Tiwari, R.K., V.K. Sachan, N.K. Singh, P. Nautiyal, G. Papnai, \& J. P. Gupta. 2014. Effect of supplementing mineral mixture daily on body weight gain in male goats. J. Krishi Vigyan. 3: 24-26. https://doi.org/10.5958/2349-4433.2014.01243.4
Ullah, N., M. Anwar, S. M. H. Andrabi, M. S. Ansari, S. Murtaza, Q. Ali, \& M. Asif. 2010. Effect of mineral supplementation on post partum ovarian activity in Nili-Ravi buffaloes (Bubalus bubalis). Pakistan J. Zool. 43:195-200.

Wang, H, Z. Liu, M. Huang, S. Wang, D. Cui, S. Dong, S. Li, Z. Qi, \& Y. Liu. 2016. Effects of long-term mineral block supplementation on antioxidants, immunity, and health of Tibetan sheep. Biol. Trace. Elem. Res. 172:326-335. https:// doi.org/10.1007/s12011-015-0593-Z

Yatoo, M.I., A. Saxena, P.M. Deepa, B.P. Habeab, S. Devi, R.S. Jatav, \& U. Dimri. 2013. Role of trace elements in animals: a review. Vet. World 6: 963-967. https://doi.org/10.14202/ vetworld.2013.963-967 